\title{
Avaliação de métodos de preservação de amostras de plantas de Savanas Neotropicais para a obtenção de DNA de alta qualidade para estudos moleculares
}

\author{
FABÍOLA FERES ${ }^{1,4}$, ANETE P. DE SOUZA ${ }^{2,3}$, MARIA DO CARMO E. DO AMARAL ${ }^{1}$ e \\ VOLKER BITTRICH ${ }^{1}$
}

(recebido: 29 de janeiro de 2004; aceito: 6 de janeiro de 2005)

\begin{abstract}
Evaluation of methods of neotropical savanna plant samples preservation for yielding high quality DNA for molecular studies). Methods for the preservation of leaf sample from plants occurring in neotropical savannas were compared, with the aim to get high quality DNA for molecular studies. Different methods for DNA isolation of the same samples were also compared. The DNA quality was evaluated by two empirical methods: digestion of the DNA with three restriction enzymes and by amplification of the mitochondrial cox3 gene by PCR. The results show that, for the savanna plants investigated, the most commonly employed method for plant sample preservation (quick dehydratation using silica gel) is not the most efficient. Our results demonstrate the importance of testing different methods of plant tissue preservation for molecular studies to guarantee high quality DNA. For plants from neotropical savannas, the silica gel method might be often less efficient than other equally simple methods of sample preservation.
\end{abstract}

Key words - DNA isolation, molecular analysis, molecular systematics, sample preservation, tropical savanna plants

RESUMO - (Avaliação de métodos de preservação de amostras de plantas de savanas neotropicais para a obtenção de DNA de alta qualidade para estudos moleculares). Foram comparadas metodologias para preservação de amostras de folhas de plantas de savanas neotropicais, visando a posterior obtenção de DNA de alta qualidade para estudos moleculares. Foram também testadas diferentes metodologias para extração de DNA das amostras investigadas. A qualidade do DNA extraído foi avaliada através de dois métodos: por digestão, utilizando-se três enzimas de restrição e através da amplificação do gene mitocondrial cox3 (subunidade III da citocromo oxidase) por PCR. Os resultados revelaram que, para as plantas de savanas investigadas, a metodologia de preservação de amostras mais comumente empregada pelos botânicos (desidratação rápida usando sílica-gel) não é a mais eficiente. Os resultados obtidos demonstram a importância de testar diferentes métodos de preservação de amostras vegetais para estudos moleculares, para garantir a obtenção de DNA de alta qualidade. Para as plantas de savanas neotropicais, o método de preservação em sílica gel pode ser menos eficiente do que outros métodos igualmente simples de preservação de amostras.

Palavras-chave - análises moleculares, extração de DNA, plantas de savanas tropicais, preservação de amostras, sistemática molecular

\section{Introdução}

Nos últimos anos, estudos envolvendo marcadores moleculares têm tido uma importância cada vez maior na sistemática vegetal. Tal fato pode ser facilmente comprovado pelo aumento exponencial de publicações de trabalhos que utilizam caracteres de DNA para a

\footnotetext{
1. Universidade Estadual de Campinas, Instituto de Biologia, Departamento de Botânica, Caixa Postal 6109, 13083-970 Campinas, SP, Brasil.

2. Universidade Estadual de Campinas, Centro de Biologia Molecular e Engenharia Genética, Laboratório de Análise Genética e Molecular, Caixa Postal 6010, 13083-970 Campinas, SP, Brasil.

3. Universidade Estadual de Campinas, Instituto de Biologia, Departamento de Genética e Evolução, Caixa Postal 6109, 13083-970 Campinas, SP, Brasil.

4. Autor para correspondência: fferes@bol.com.br
}

reconstrução da filogenia de um ou vários grupos de plantas ou para estudos filogeográficos. Concomitantemente aos estudos filogenéticos, a metodologia de coleta, tratamento e conservação de amostras de plantas para estudos moleculares tem sido intensamente debatida (Doyle \& Dickson 1987, Chase \& Hills 1991, Sytsma et al. 1993, Taylor \& Swann 1994, Dessauer et al. 1996). Naturalmente, a obtenção de DNA de boa qualidade é um passo fundamental para o sucesso das análises moleculares.

A experiência mostra que a utilização de material fresco é ideal para a realização de estudos moleculares (Sytsma et al. 1993). Entretanto, nos estudos com plantas silvestres, isso nem sempre é possível. $\mathrm{Na}$ maioria dos casos, as plantas ocorrem em locais distantes dos centros de pesquisa e o seu cultivo pode ser difícil, como ocorre com muitas plantas de cerrado e de campo rupestre. Por esses motivos, o método mais 
comumente utilizado para preservar amostras para posterior extração de DNA é a rápida desidratação, principalmente de folhas, em sílica gel (Chase \& Hills 1991). Tal método oferece inúmeras vantagens, principalmente, devido à sua simplicidade, otimização de espaço físico tanto para o transporte quanto para seu armazenamento no laboratório e também pela preservação do DNA das amostras dessecadas por um longo prazo. Outras vantagens de se usar tecido seco em estudos moleculares é o fato dele poder ser rompido com maior facilidade e a qualidade do DNA ser, em geral, bastante satisfatória. Além disso, no estado desidratado, o DNA é menos suscetível à degradação química ou enzimática (Murray \& Thopmson 1980).

Entretanto, nossa experiência na extração de DNA de folhas de plantas coletadas em cerrados ou campos rupestres e desidratadas em sílica gel demonstrou que esta metodologia pode não ser adequada para a obtenção de DNA de alta qualidade de tais espécies.

A partir desse fato, foram feitos testes utilizando várias metodologias de conservação de amostras de plantas, simulando as condições encontradas no campo durante as expedições de coleta. Foram testados diferentes tipos de processamento dessas amostras no laboratório. Esses testes foram realizados levando-se em consideração o tempo médio gasto entre a coleta da amostra e a extração de seu DNA no laboratório.

As savanas tropicais no Brasil, especialmente o cerrado e os campos rupestres, são de grande importância, tanto pelo tamanho das áreas que cobrem quanto pelo alto endemismo de suas floras e, infelizmente, pela ameaça da extinção de muitas das suas espécies. O cerrado é uma formação vegetal característica do Planalto Central do Brasil. As plantas que ali ocorrem são adaptadas a uma forte estação seca, a solos ácidos e oligotróficos e à ação do fogo (Joly 1970). Os campos rupestres ocorrem em serras, geralmente em altitudes superiores a $1.000 \mathrm{~m}$, em formações de afloramentos de quartzitos ou arenitos com solo pouco profundo (Joly 1970). As plantas que ocorrem em cerrados ou em campos rupestres apresentam, freqüentemente, folhas coriáceas com cutículas espessas e outras características xeromorfas. As características xeromorfas das plantas do cerrado foram interpretadas inicialmente como uma adaptação à seca (Warming \& Ferri 1973). Outros autores atribuíram a presença desses caracteres à falta de nutrientes disponíveis nos solos (escleromorfismo oligotrófico, Arens 1958) ou à acidez dos solos aliada à toxicidade do alumínio (Goodland 1971). Estudos clássicos (Ferri 1944, Rawitscher 1948) constataram que espécies arbóreas de cerrado com folhas escleromorfas transpiram normalmente durante a estação das secas. Isso seria devido ao fato de possuírem raízes profundas, o que possibilitaria um suprimento hídrico adequado, mesmo na estação das secas. Outros estudos, entretanto, revelaram que espécies do cerrado podem exercer um controle estomático rígido nas taxas de transpiração, por não conseguir extrair água do solo em quantidade suficiente para fazer frente à alta demanda evaporativa da atmosfera durante a época das secas (Naves-Barbiero et al. 2000). Pouco se conhece sobre a ecofisiologia das plantas que ocorrem em campos rupestres, mas algumas espécies parecem ser extremamente adaptadas ao estresse hídrico. Estudos revelaram que folhas isoladas de Nanuza plicata (Mart.) L.B. Sm. \& Ayensu, desidratadas durante longo tempo, podem permanecer em estado latente até receberem novamente água, quando então reassumem a atividade de fotossíntese (Meguro et al. 1977).

O presente trabalho tem como principal objetivo comparar a integridade do DNA extraído a partir de amostras de folhas de espécies provenientes de cerrado ou de campos rupestres coletadas, armazenadas e processadas por meio de diferentes metodologias. A eficácia das diferentes metodologias de extração de DNA e de conservação das amostras foi avaliada através da digestão do DNA extraído por três enzimas de restrição (EcoRI, EcoRV e HindIII) e também da amplificação do DNA por PCR, empregando-se iniciadores (primers) para a amplificação do gene mitocondrial que codifica a subunidade III da citocromo oxidase (cox3).

\section{Material e métodos}

Para a avaliação das diferentes metodologias de coleta e preservação de material vegetal foi utilizada a espécie Kielmeyera lathrophyton Saddi, cultivada no Instituto de Biologia da Unicamp. Essa espécie ocorre em matas semidecíduas, sendo também encontrada em cerrados nos Estados de Minas Gerais, São Paulo, Goiás e no Distrito Federal (Saddi 1987). Testes adicionais foram realizados com as espécies Kielmeyera petiolaris Mart., Ditassa lenheirensis Silveira, Lychnophora salicifolia Mart., Wunderlichia mirabilis Riedel ex Baker, Banisteriopsis angustifolia (A. Juss) B. Gates e Hypenia vitifolia (Pohl ex Benth.) Harley, que ocorrem em campos rupestres de Minas Gerais, Bahia e Goiás.

Na primeira etapa das avaliações, foram coletadas cinco amostras de folhas de Kielmeyera lathrophyton. Cada amostra foi submetida a diferentes tipos de tratamento, visando a sua conservação (tabela 1), em condições de campo 
e/ou laboratório que poderiam ser encontradas durante o desenvolvimento de um trabalho de coleta.

Passados sete dias dos respectivos tratamentos, as amostras 01, 03 e 05 foram moídas em nitrogênio líquido, enquanto a amostra 02 foi moída com um pouco de sílica gel em um almofariz, com auxílio de um pistilo. A amostra 04 foi coletada e moída em nitrogênio líquido cerca de três dias antes de ser realizada a extração de seu DNA. As amostras dos tratamentos $01,03,04$ e 05 foram estocadas a $-70{ }^{\circ} \mathrm{C}$ após a moagem, para futura extração de DNA. A amostra 02 foi estocada a $-20{ }^{\circ} \mathrm{C}$ após a moagem.

Na segunda etapa das avaliações, foram coletadas três amostras de folhas de Kielmeyera lathrophyton (06, 07 e 08, tabela 1), as quais diferiram dos tratamentos 01,03 e 05 pelo fato de terem sido conservadas por 15 dias nas condições descritas na tabela 1 e pela amostra 08 ter sido congelada a $-20{ }^{\circ} \mathrm{C}$. Após o período de 15 dias, as amostras 06, 07 e 08 foram moídas em nitrogênio líquido em um almofariz com auxílio de um pistilo e em seguida estocadas a $-70^{\circ} \mathrm{C}$, procedimento idêntico ao efetuado para as amostras 01,03 , 04 e 05.

O DNA das oito amostras de $K$. lathrophyton foi extraído através dos métodos que empregam tampão de extração com CTAB (brometo de cetil-trimetilamônio), descritos por Doyle \& Doyle (1990) e por Romano \& Brasileiro (1999). Também foi realizada a extração do DNA das amostras utilizando-se o "kit" Nucleon Phytopure (Amersham/Life Science), o qual emprega uma resina capaz de remover compostos polissacarídeos e/ou polifenóis que possam estar presentes nas amostras. Em todas as extrações de DNA, foram utilizados $100 \mathrm{mg}$ de tecido de cada amostra.
Após a extração, uma alíquota de $10 \mu \mathrm{L}$ do DNA de cada uma das amostras foi quantificada em gel de agarose $0,8 \%$, em comparação com um padrão de concentração previamente estabelecido, o qual foi o DNA do fago $\mathrm{O}$, variando-se sua concentração de 25 a 150 ng. $\mu \mathrm{L}^{-1}$. Após a eletroforese, o gel foi corado com brometo de etídeo e o DNA visualizado sob a luz UV. Em seguida, o gel foi fotografado com câmera polaroid.

O DNA das amostras de Kielmeyera lathrophyton, obtido nos oito tratamentos, foi digerido utilizando-se três enzimas de restrição: EcoRI, EcoRV e HindIII. Para um volume final de digestão de $50 \mu \mathrm{L}$ foram utilizados: $30 \mu \mathrm{L}$ do DNA de cada amostra (concentração aproximada de $500 \mathrm{ng}$ ), 2,5 mM de espermidina, tampão da enzima $1 \mathrm{X}, 2 \mathrm{U} . \mu \mathrm{L}^{-1}$ de enzima e água ultrapura esterilizada em autoclave para completar $\mathrm{o}$ volume final. As reações foram incubadas em banho-maria a $37{ }^{\circ} \mathrm{C}$ por duas horas. Após a incubação, foram retiradas alíquotas de $10 \mu \mathrm{L}$ de cada reação de digestão para realizar uma eletroforese em gel de agarose $0,8 \%$, o gel foi corado e fotografado como descrito anteriormente. $\mathrm{O}$ marcador de peso molecular utilizado no gel da digestão foi o DNA do fago Mx174 digerido pela enzima HaeIII, juntamente com o DNA do fago Odigerido pela enzima HindIIII.

As reações de amplificação por PCR utilizando-se primers do gene mitoncodrial cox3 com o DNA das amostras de Kielmeyera lathrophyton foram conduzidas em um termociclador (PTC-100, MJ Research Inc.), cujo programa constou de: desnaturação inicial a $94{ }^{\circ} \mathrm{C}$ por dois minutos e trinta segundos, 30 ciclos de desnaturação a $94{ }^{\circ} \mathrm{C}$ por um minuto, anelamento a $60{ }^{\circ} \mathrm{C}$ por dois minutos, e extensão a $72{ }^{\circ} \mathrm{C}$ por 3 minutos. Após os 30 ciclos, a extensão final foi de $72{ }^{\circ} \mathrm{C}$ por sete minutos, e incubação (soak) a $15^{\circ} \mathrm{C}$ ao término

Tabela 1. Tratamentos realizados para a conservação das amostras de Kielmeyera lathrophyton Saddi antes da extração de DNA.

Table 1. Performed storage treatments for preservation of Kielmeyera lathrophyton Saddi samples before DNA isolation.

\begin{tabular}{|c|c|c|}
\hline Tratamento & Descrição do tratamento realizado & Período \\
\hline 01 & $\begin{array}{l}\text { Folha envolvida em papel toalha, acondicionada em saco plástico com fecho hermético, } \\
\text { mantida ao abrigo da luz, à temperatura ambiente }\end{array}$ & 7 dias \\
\hline 02 & $\begin{array}{l}\text { Folha desidratada em sílica gel, acondicionada em saco plástico com fecho hermético, } \\
\text { mantida ao abrigo da luz, à temperatura ambiente }\end{array}$ & 7 dias \\
\hline 03 & $\begin{array}{l}\text { Folha armazenada em saco plástico com fecho hermético e mantida resfriada em isopor } \\
\text { com gelo (trocas diárias do gelo) }\end{array}$ & 7 dias \\
\hline 04 & Folha fresca macerada em nitrogênio líquido e armazenada a $-70^{\circ} \mathrm{C}$ & 3 dias \\
\hline 05 & $\begin{array}{l}\text { Folha armazenada em saco plástico com fecho hermético, embrulhada em papel jornal e } \\
\text { mantida resfriada em isopor com gelo (trocas diárias do gelo) }\end{array}$ & 7 dias \\
\hline 06 & $\begin{array}{l}\text { Folha armazenada em saco plástico com fecho hermético, embrulhada em papel jornal e } \\
\text { mantida resfriada em isopor com gelo (trocas diárias) }\end{array}$ & 15 dias \\
\hline 07 & $\begin{array}{l}\text { Folha envolvida em papel toalha, acondicionada em saco plástico com fecho hermético, } \\
\text { mantida ao abrigo da luz, à temperatura ambiente }\end{array}$ & 15 dias \\
\hline 08 & $\begin{array}{l}\text { Folha acondicionada em saco plástico com fecho hermético e imediatamente congelada } \\
\text { em freezer }\left(-20^{\circ} \mathrm{C}\right)\end{array}$ & 15 dias \\
\hline
\end{tabular}


do programa. O volume final da reação de amplificação do DNA foi de $25 \mu \mathrm{L}$, sendo: $1 \mu \mathrm{L}$ de DNA (concentração aproximada de $10 \mathrm{ng}$ ), 5 pmol de cada um dos dois primers (primer 3: 5' ATG ATT GAATCT CAGAGGCAT 3' e primer 4: 5'AAG CCC GGT TCT CTT TGT CTT 3', Siqueira et al. 2002), 0,2 $\mu$ l de Taq-polimerase (Gibco BR), 1X do tampão para PCR fornecido pelo fabricante da enzima, 2,5 $\mathrm{mM}$ de uma solução resultante da mistura dos quatro dNTPs (concentração final de $100 \mu \mathrm{M}$ na reação de amplificação de cada dNTP), 2,5 mM de $\mathrm{MgCl}_{2}, 2,0 \mu \mathrm{L}$ de PVP (polivinilpirrolidona) a 1\%, e água ultrapura esterilizada em autoclave para completar o volume final. Após a reação de amplificação, foram retiradas alíquotas de $10 \mu \mathrm{L}$ de cada reação, as quais foram submetidas à eletroforese em gel de agarose a $1 \%$. Em seguida, o gel foi corado e fotografado como descrito anteriormente. $\mathrm{O}$ marcador de peso molecular utilizado foi o mesmo empregado no gel efetuado para a visualização da digestão do DNA.

\section{Resultados e Discussão}

Considerando-se as amostras da primeira etapa do teste, as quais permaneceram armazenadas durante sete dias antes da moagem, observou-se que as amostras 01 e 05 (folhas envolvidas em papel, mantidas à temperatura ambiente ou resfriadas em isopor com gelo, respectivamente) tiveram excelente conservação nas condições descritas (figura 1A, 1C, respectivamente). Entretanto, a amostra 03 (folhas em contato direto com o gelo) demonstrou ligeira degradação foliar (figura 1B), provavelmente ocasionada pela lise celular devido ao contato da folha com o gelo. A amostra 02, desidratada com sílica gel, secou em menos de 12 horas. Tal resultado indicou que o processo de desidratação ocorreu satisfatoriamente pois, segundo Sytsma et al. (1993), caso a amostra leve mais do que 12 horas após sua coleta para secar, pode ocorrer a degradação do seu DNA.

Analisando-se as amostras da segunda etapa do teste (15 dias de armazenamento), observou-se que a amostra 06 (figura 1E) exibiu melhor conservação que a amostra 07 (folhas envolvidas em papel, resfriadas em isopor com gelo ou mantidas à temperatura ambiente, respectivamente). A amostra 07 apresentou elevado grau de degradação, evidenciado pela coloração extremamente escura da folha (figura 1D). A amostra 08 (conservada a $-20{ }^{\circ} \mathrm{C}$ ) não apresentou degradação foliar (resultado não mostrado).

Nossos resultados revelaram que os dois métodos de extração de DNA que empregam CTAB testados (Doyle \& Doyle 1990, Romano \& Brasileiro 1999) foram ineficazes para obtenção de DNA de Kielmeyra lathrophyton (resultados não mostrados). Apesar de inúmeras repetições efetuadas, não foram observadas bandas de DNA nos géis de agarose realizados após as extrações. A extração de DNA somente foi bem sucedida utilizando-se o "kit" de extração Nucleon Phytopure (figura 2).

Sete das oito metodologias utilizadas para armazenamento das amostras de $K$. lathrophyton mostraram-se eficazes quanto à sua preservação visando a obtenção de DNA, o que pode ser constatado pela presença de bandas de DNA na figura 2. A única exceção observada foi a amostra desidratada em sílica gel, uma vez que não foi visualizada banda de DNA no gel (figura 2, número 02). Mesmo para as amostras que mostraram um certo grau de degradação do tecido foliar, como na amostra 07 (folha mantida durante 15 dias à temperatura ambiente), a extração de DNA foi bem sucedida. O DNA extraído apresentou uma boa qualidade e quantidade suficiente (de 1 a $2 \mathrm{mg}$ ) para sua utilização em várias das técnicas moleculares, normalmente, empregadas em filogenia molecular.

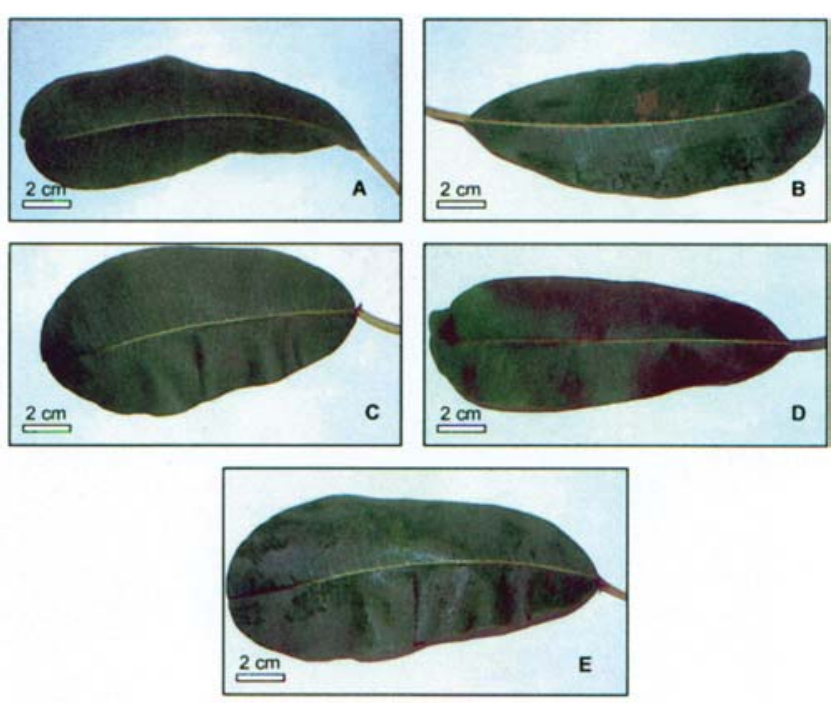

Figura 1. Amostras de folhas de Kielmeyera lathrophyton Saddi submetidas a diferentes tipos de tratamento e de armazenamento. A, D = folhas mantidas à temperatura ambiente; $\mathrm{B}=$ folha mantida no gelo sem proteção de papel jornal; $\mathrm{C}, \mathrm{E}=$ folhas mantidas no gelo, protegidas por papel jornal. A-C $=7$ dias de armazenamento; $\mathrm{D}, \mathrm{E}=15$ dias de armazenamento.

Figure 1. Leaf samples of Kielmeyera lathrophyton Saddi submitted to different storage treatments. A, D = leaves maintained at room temperature; $\mathrm{B}=$ leaf maintained on ice without the newspaper sheets protection; $\mathrm{C}, \mathrm{E}=$ leaves maintained on ice with the newspaper sheets protection. $\mathrm{A}-\mathrm{C}=7$ days of treatment; $\mathrm{D}, \mathrm{E}=15$ days of treatment. 


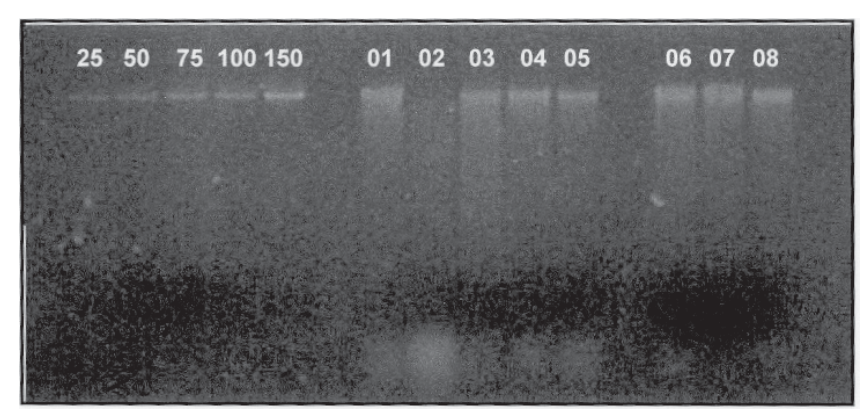

Figura 2. Análise eletroforética do DNA extraído das amostras de Kielmeyera lathrophyton Saddi em gel de agarose 0,8\%. As diferentes concentrações do padrão de peso molecular (fago O) correspondem a 25, 50, 75, 100 e 150 ng aplicados no gel. Os números 01 a 08 correspondem às amostras submetidas aos diferentes tipos de tratamento e períodos de armazenamento, conforme indicado na tabela 1.

Figure 2. Electrophoretical analysis of the isolated DNA from Kielmeyera lathrophyton Saddi samples, in a $0.8 \%$ agarose gel. Lanes indicated as 25 to 150 refers to different molecular weight marker concentration $(\mathrm{Q}$, in $\mathrm{ng})$. Lanes indicated as 01 to 08 refers to the DNA isolated from samples of K. lathrophyton Saddi that were submitted to different storage treatments, as explained on table 1.

Os resultados, sobre a qualidade do DNA obtido nas avaliações dos diferentes tipos de procedimentos de coleta, indicaram que o procedimento mais eficiente e mais fácil em condições de campo foi o tratamento 01 (folhas mantidas à temperatura ambiente durante uma semana). Sendo assim, foram efetuadas coletas de amostras de populações de espécies de campos rupestres como Kielmeyera petiolaris, Ditassa lenheirensis, Lychnophora salicifolia, Wunderlichia mirabilis, Banisteriopsis angustifolia e Hypenia vitifolia, utilizando-se o mesmo tratamento 01. O DNA extraído dessas amostras apresentou excelente qualidade (resultados não mostrados), confirmando os resultados inicialmente obtidos.

Com a finalidade de testar a qualidade do DNA para ensaios de digestão enzimática, o DNA de sete das oito amostras em estudo (excluindo-se a amostra 02, desidratada em sílica gel, da qual não se obteve DNA) de Kielmeyera lathrophyton foi digerido por três diferentes enzimas de restrição. Como pode ser visualizado na figura 3 , as digestões foram bem sucedidas para as amostras.

$\mathrm{Na}$ figura 4, podemos observar os resultados da reação de amplificação do gene mitocondrial cox3. O gene foi amplificado com sucesso nas amostras 01, 03, 04, 05 e 08, o que pode ser constatado pela intensidade e presença de uma única banda para cada amostra no gel, além da equivalência à banda correspondente ao peso molecular, situada entre 0,6 a $0,8 \mathrm{~Kb}$ (Siqueira et al. 2002). Entretanto, mesmo após repetidos testes, não foi possível amplificar esse gene nas amostras 06 e 07 (folhas mantidas no gelo ou em temperatura ambiente, respectivamente, durante 15 dias). Em todos os experimentos, os respectivos controles negativos tampouco tiveram fragmentos amplificados. Uma explicação para a não amplificação dessas duas amostras pode residir no tempo relativamente longo de armazenamento que pode ter causado degradação do tecido foliar. Apesar de o DNA dessas amostras ter sido extraído com sucesso, é possível que a degradação dos tecidos tenha permitido a liberação de compostos secundários. Compostos secundários, particularmente os fenólicos, são conhecidos por agir inibindo a ação da enzima Taq-polimerase, impedindo, portanto a amplificação do DNA.

Foram realizadas também reações de amplificação por PCR para as regiões ITS I e II (DNA nuclear

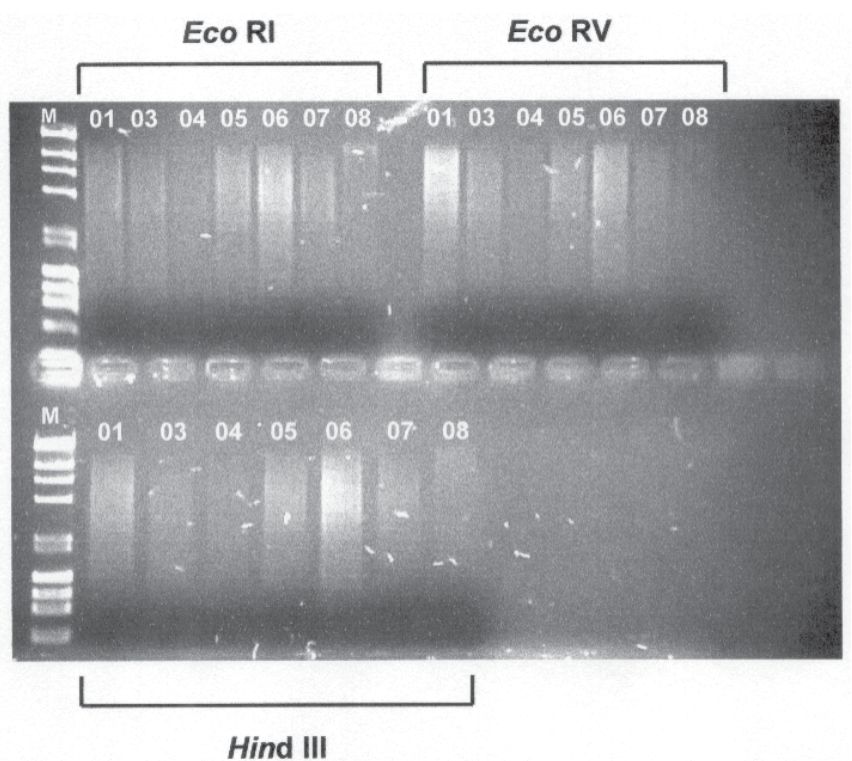

Figura 3. Gel de agarose $0,8 \%$ contendo o DNA das amostras de Kielmeyera lathrophyton Saddi (01, 03, 04, 05, 06, 07 e 08) digeridas pelas enzimas EcoRI, EcoRV e HindIII. M = marcador de peso molecular OHindIII Mk174/ HaeIII.

Figure 3. DNA digestion electrophoresis of Kielmeyera lathrophyton Saddi samples (lanes 01, 03, 04, 05, 06, 07 and 08 ) in a $0.8 \%$ agarose gel. Digestion performed by the enzymes EcoRI, EcoRV and HindIII. $\mathrm{M}=$ molecular weight marker ( $\mathrm{O}$ HindIII Mx174/HaeIII). 


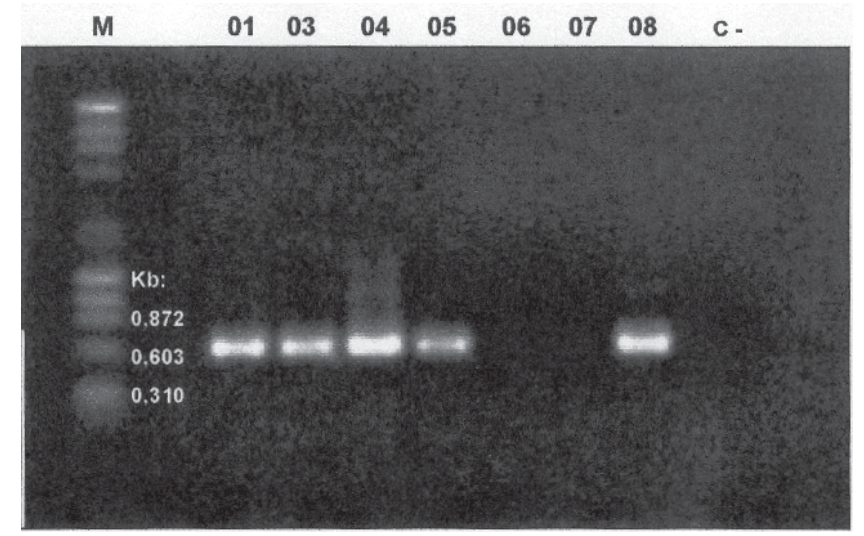

Figura 4. Eletroforese dos produtos de amplificação por PCR do gene cox3 das amostras de Kielmeyera lathrophyton Saddi em gel de agarose $1 \%$. Os números 01 a 08 correspondem às amostras submetidas aos diferentes tratamentos mencionados na tabela $1 . \mathrm{M}=$ marcador de peso molecular OHindIII Mk174/ HaeIII. Kb = kilobases.

Figure 4. Electrophoresis of PCR products obtained form the amplification of cox3 gene from Kielmeyera lathrophyton Saddi samples in a $1 \%$ agarose gel. The numbers 01 to 08 means the samples submitted to the different storage treatments explained on table $1 . \mathrm{M}=$ molecular weight marker OHindIII Mx174/ HaeIII. Kb = kilobases.

ribossomal) e trnL (DNA de cloroplasto). Para essas regiões, as amostras que amplificaram com maior facilidade foram 03, 04 e 08 (resultados não mostrados).

Após as reações de digestão de DNA por enzimas de restrição e de amplificação do DNA por PCR, concluímos que o método mais eficiente visando a coleta e preservação das amostras de plantas é o tratamento que mantém as folhas resfriadas em isopor com gelo, protegidas por papel jornal (tratamento 05). Nesse tratamento, a amostra permanece ao abrigo da luz, em baixa temperatura e sem contato direto com o gelo, o que impede a degradação do tecido foliar. Esse tratamento pode ser empregado por um período de sete dias, sem ocorrerem perdas significativas na qualidade e quantidade de DNA extraído e sem comprometer o sucesso de técnicas moleculares que empregam a digestão do DNA e amplificação de genes ou de regiões do genoma.

Em relação ao método de desidratação de folhas em sílica gel, é possível que as plantas aqui investigadas produzam compostos secundários que são extraídos juntamente com o DNA. Aparentemente, é extremamente difícil separar esses compostos durante a extração de DNA.

$\mathrm{O}$ método de armazenamento empregado para a amostra 08 , onde as folhas frescas foram estocadas a
$-20{ }^{\circ} \mathrm{C}$, consiste na mesma metodologia que foi utilizada por Manubens et al. (1999), para amostras de folhas de pêssego e nectarina. $\mathrm{O}$ congelamento da folha fresca a $-20{ }^{\circ} \mathrm{C}$ resulta no extravasamento do conteúdo celular, pois ocorre a quebra da parede celular devido à cristalização do líquido celular. Tal extravasamento do líquido celular resulta em uma redução significativa da quantidade de DNA obtido do material. Mesmo assim, a amostra submetida a esse tratamento (08) parece não ter tido o seu DNA danificado ou significativamente reduzido, de modo que não houve nenhum comprometimento nas reações de digestão do DNA com enzimas de restrição e nem com a sua amplificação por PCR.

Os métodos de extração do DNA que usam CTAB não foram eficazes para Kielmeyera lathrophyton e nem para $K$. petiolaris. O único método eficaz para extrair o DNA de amostras dessas espécies foi o "kit" Nucleon Phytopure (Amersham/Life Science). Apesar de serem relativamente caros, os "kits" de extração de DNA possuem inúmeras vantagens, dentre elas está a padronização das soluções e de seu pH. Além disso, os "kits" utilizam, em geral, resinas, filtros ou soluções que removem compostos fenólicos e/ou polissacarídeos presentes na amostra com notável eficácia, através do princípio de ligação iônica ou de precipitação em sal.

Dos resultados das avaliações apresentadas no presente trabalho, emerge uma questão de extrema importância para o sucesso de qualquer estudo molecular envolvendo plantas neotropicais: a necessidade de, em primeiro lugar, otimizar a metodologia de coleta e de conservação das amostras que deverá ser empregada durante a execução do trabalho. Esse procedimento deve ser feito antes do início efetivo das coletas das amostras no campo. Afinal, da otimização dessa etapa inicial de coleta e armazenamento do material vegetal, dependerá o sucesso das etapas subseqüentes de qualquer estudo molecular, como a extração de DNA, a amplificação do DNA por PCR ou sua digestão por enzimas de restrição.

Por outro lado, deve-se ficar atento ao fato de que um método de preservação do material pode ser eficiente para uma determinada espécie e ineficaz para outra. Os resultados revelaram que para plantas de cerrados e de campos rupestres, de um modo geral, a desidratação de folhas em sílica gel não parece ser um método eficaz para posterior extração de DNA. Provavelmente, esse fato pode ser explicado pelo tipo de ambiente que essas plantas vivem. Devido às condições ambientais extremas, como falta de nutrientes do solo, estresse hídrico e alta irradiação solar, características desses ambientes, as folhas de muitas 
espécies que ocorrem em cerrados e campos rupestres podem ser adaptadas a resistir à desidratação. Por isso, a desidratação do material em sílica gel pode não ser suficientemente rápida para permitir a preservação de seu DNA. Além disso, também devido a uma adaptação contra herbívoros, as plantas de campos rupestres e de cerrados podem ter altos níveis de compostos secundários como compostos fenólicos, que dificultam ou inviabilizam as reações de PCR, por inibirem a enzima Taq-polimerase (Hummel \& Herrmann 1994), ou de polissacarídeos.

As conclusões aqui apresentadas não se aplicam, necessariamente, a ambientes como matas pluviais úmidas ou ambientes palustres. É aconselhável, no entanto, testar metodologias diferentes no início de qualquer estudo com caracteres moleculares, incluindo métodos de conservação de amostras e de extração de DNA, para evitar, posteriormente, uma eventual perda de tempo e de recursos.

As diferentes metodologias apresentadas e avaliadas no presente trabalho são extremamente simples e de custo financeiro muito baixo, podendo ser testadas e empregadas em qualquer instituição de pesquisa.

Agradecimentos - Agradecemos ao Juverlande Lugli pelo apoio e sugestões sobre as coletas durante o desenvolvimento deste trabalho, ao CNPq (Processo 141906/01) e à Fapesp pelo Auxílio à Pesquisa concedido (Processo 01/08658-8). As três primeiras autoras são bolsistas do CNPq.

\section{Referências bibliográficas}

ARENS, K. 1958. O cerrado como vegetação oligotrófica. Boletim da Faculdade de Filosofia, Ciências e Letras da Universidade de São Paulo 224 Botânica 15:59-77.

CHASE, M.W. \& HILLS, H.H. 1991. Silica gel: an ideal material for field preservation of leaf samples for DNA studies. Taxon 40:215-220.

DESSAUER, H.C, COLE, C.J. \& HAFNER, M.S. 1996. Collection and storage of tissues. In Molecular systematics, $2^{\text {nd }}$ ed (D.M. Hillis, C. Moritz \& B.K. Mable, eds.). Sinauer, Sunderland, p.29-47.

DOYLE, J.J. \& DICKSON, E.E. 1987. Preservation of plant samples for DNA restriction endonuclease analysis. Taxon 36:715-722.

DOYLE, J.J. \& DOYLE, J.L., 1990. Isolation of plant DNA from fresh tissue. Focus 12:13-15.

FERRI, M.G. 1944. Transpiração de plantas permanentes dos "cerrados". Boletim da Faculdade de Filosofia, Ciências Letras Universidade de São Paulo 41. Botânica 4:155-224.

GOODLAND, R.J.A. 1971. Oligotrofismo e alumínio no cerrado. In III Simpósio sobre o cerrado (M.G., Ferri, ed.). Edusp, Edgard Blücher, São Paulo, p.44-60.
HUMMEL, S. \& HERRMANN, B. 1994. General aspects of sample preparation. In Ancient DNA: Recovery and Analysis of Genetic Material from Paleontological, Arhcaeological, Museum, Medical, and Forensic Specimens (B. Herrmann \& S. Hummel, eds.). SpringerVerlag, New York, p.59-67.

JOLY, A.B. 1970. Conheça a vegetação brasileira. Edusp, Polígono, São Paulo.

MANUBENS, A., LOBOS, S., JADUE, Y., TORO, M., MESSINA, R., LLADSER, M. \& SEELENDFREUND, D. 1999. DNA isolation and AFLP fingerprinting of nectarine and peach varieties (Prunus persica). Plant Molecular Biology Reporter 17:255-267.

MEGURO, M., JOLY, C.A. \& BITTENCOURT, M.M. 1977. "Stress" hídrico e alguns aspectos do comportamento fisiológico em Xerophyta plicata Spreng. - Velloziaceae. Boletim de Botânica da Universidade de São Paulo 5:27-42.

MURRAY, M.G. \& THOMPSON, W.F. 1980. Rapid isolation of high molecular weight plant DNA. Nucleic Acids Research 8: 4321-4325.

NAVES-BARBIERO, C.C., FRANCO, A.C., BUCCI, S.J. \& GOLDSTEIN, G. 2000. Sap flow and stomatal conductance of two evergreen woody species in an open savanna and a savanna woodland. Revista Brasileira de Fisiologia Vegetal 12:119-134.

RAWITSCHER, F.K. 1948. The water economy of the vegetation of the "campos cerrados" in southern Brazil. Journal of Ecology 36:236-268.

ROMANO, E. \& BRASILEIRO, A.C. M. 1999. Extração de DNA de plantas. Biotecnologia 9:40-43.

SADDI, N. 1987. New species of Kielmeyera (Guttiferae) from Brazil. Kew Bulletin 42:221- 230

SIQUEIRA, S.F., DIAS, S.M.G., HARDOUIN, P., PEREIRA, F.R.S., LEJEUNE, B. \& SOUZA, A.P. 2002. Transcription of succinate dehydrogenase subunit $4(s d h 4)$ gene in potato: detection of extensive RNA editing and cotranscription with cytochrome oxidase subunit III (cox3) gene. Current Genetics 41:282-289.

SYTSMA, K., GIVNISH, T.J., SMITH, J.F., \& HAHN, W.J. 1993. Collection and storage of land plant samples for macromolecular comparisons. In Methods in Enzymology - Molecular Evolution: Producing the Biochemical Data (E.A. Zimmer, T.J. White, R.L. Cann \& A.C. Wilson, eds.). Academic Press, San Diego. v.24, p.23-38.

TAYLOR, J.W. \& SWANN, E.C. 1994. Dried Samples: Soft Tissues - DNA from Herbarium Specimens. In Ancient DNA: Recovery and Analysis of Genetic Material from Paleontological, Arhcaeological, Museum, Medical, and Forensic Specimens (B. Herrmann \& S. Hummel, eds.). Springer-Verlag, New York, p.167-181.

WARMING, E. \& FERRI, M.G. 1973. Lagoa Santa e a vegetação de cerrados brasileiros. Itatiaia, Edusp, Belo Horizonte. 